\title{
FNTA Gene
}

National Cancer Institute

\section{Source}

National Cancer Institute. FNTA Gene. NCI Thesaurus. Code C38599.

This gene plays a role in subcellular protein targeting and the post-translational

modification of certain proteins. 